\title{
Showcasing Nigeria through the Home Videos
}

\author{
${ }^{1}$ Alawode, Sunday Olayinka, ${ }^{2}$ Sunday, Uduakobong \\ ${ }^{I}$ (Ph.D) Adebola Adegunwa School of Communication 21 Olufemi Street, Off Nathan Street, Surulere - Lagos \\ ${ }^{2}$ Adebola Adegunwa School of Communication 21 Olufemi Street, Off Nathan Street, Surulere - Lagos
}

\begin{abstract}
Despite the diverse potentials and opportunities available in Nigeria and with Nigerians, there seems to be lack of effective medium or mechanism to project them attractively to the world. The home video phenomenon being an emergent and celebrated art is a veritable and accessible means of communication which can be pivotal towards showcasing Nigeria to the world through its offerings. The need to showcase is further contingent on the increasing maltreatment of the Nigerian citizens outside its shore due to the country's negative image and/or perception by the misinformed. With the realization that home video has been widely acclaimed as being watched and appreciated all over the world, this study based on Agenda- setting as theoretical framework through content analyzing of fifty (50) video films televised by television stations in Lagos and Africa Magic (cable network) sought to determine how the film makers have showcased Nigeria through portrayals and representations in the home videos. The result reveals that the film producers extensively project the nation's traditional societies with applicable cultures, beliefs, lifestyles, values, norms, dressing and sometimes languages, amongst other things. They have also done a great deal to show Nigerians as very religious people with diverse kinds of persuasions. The lifestyle and attitudes of Nigerians in urban settings as they portray are often flawed with exaggerations of flamboyance, affluence and elegance. Other kinds of exaggerations are in their exposition of corruption, violence, ritualism, thuggery and hooliganism as well as witchcraft, occultism/cultism and other kinds of fetish acts amongst others. Very little is done in the home videos to showcase the nation's natural resources, agricultural produce, mineral resources, monumental and historical centres and settings, tourist centres and attraction as well as the nation's flags, currencies, coat of arm to mention but a few.The impacts and efficacy of offerings of the home videos, being a medium for showcasing the nation and its people would be evidenced in the responses and attitudes towards Nigeria, its products and services as well as its people.
\end{abstract}

Key Words: Home Video, Portrayals, Representation,Showcasing

\section{Introduction}

The home video in Nigerian has been recognized as an emerging art, a veritable and accessible means of communication (Ekwauzi, 2003; Alawode, 2003).It is a phenomenon prevalent in the Nigerian film industry popularly called 'Nollywood', which Jean Rouch, a champion of indigenous art in Niger has compared to AIDS virus (The Economist, 2010). The home video is basically movie produced and stored in Digital Versatile Disk (DVD) which can be watched in the comfort of a person's home or any convenient place of choice. People can be informed and educated while being entertained through this medium. The films are usually produced in different languages spoken in Nigeria including English and vernacular (which are in most cases with subtitled).

They normallyhave indigenous contents and address issues relevant to the mass audience. Through the Nigerian narrative techniques (African storylines) and western technology, the films document and recreate socio-economic, political and cultural events within and beyond the country's borders. The prices of the films range from 100 Naira to 400 Naira (less than $\$ 1.00$ to about \$2.50) depending on the age of the film. The industry has grown from obscurity to become an important phenomenon which has attracted not only world acclamation but has brought scholars, reporters, reviewers, journalists, investors and different kinds of people to the country. Some of the people come to investigate, invest and observe the industry or network with its people (Adenugba,2007). Indeed, popular opinion based on UNESCO report (2009), holds that the Nigerian film industry, which is dominated byhome videos is currently rated second in production of films after Bollywood (India) and over Hollywood (America).

\section{The Problem}

Lacey (2009) reflects on biological processes of perceiving the world around us and asserts that media studies, when analyzing text concerns with the factors that influence how we understand the world. The texts are created to communicate a message; holiday snapshot attempts to convey what it was like to be at a particular place at a specific time. However, whether we understand what was intended to be conveyed by a photograph depends upon how the audience interpretes the image. Theoretically, at the level of denotation, almost everyone 
will describe an image in exactly the same way; but this is not necessarily the case. Giving an example of an artist affected by his understanding of his world would perceive red colour as vermillion. People's interpretation of the world depends on previous experiences in life. The ultimate is that people interprete what their eyes are seeing all the time. The film (home video) provides a lot of information into people's head; even if they do not see it as 'information' and even if they are not really paying much attention, people get affected by the experiences somehow. Nelmes (2005) opines that "the media re -presents information to its audience, who are encouraged by the mainstream media to see its output as a 'window on the world', as reflecting reality."'The home videos can inform, educate, advertise, market, sell and rebrand Nigeria and all its concerns while also providing entertainment to its viewers. Considering that different categories of people come from all over the world to interact with the video makers and the producers, it is pertinent to understand why the home video industry should be of interest to all those people. The phenomenon called 'home video' must truly provide exciting appeal and aesthetics which have drawn all such people to the country. Akangbe (2008) on his part informs us thatdrama is a recreation of society and a megaphone for projecting sentiments, aspirations, failings, attainments, history, changes, etc, of a society. Thus, he asserts that drama is a veritable medium of picturising a particular society with a view to educating, informing and entertaining the audience. The question then is - what picture of Nigeria is the home video producers making their viewers to see? How does the home video showcase Nigeria?

The Advanced Learners Dictionary (2000) defines showcase as an event that presents somebody's abilities or the good qualities of something in an attractive way.Merriam- Webster Unabridged Dictionary (Online, undated)further defines it as a setting, occasion or medium for exhibiting something or someone especially in an attractive or favourable aspect. Following Akangbe's definition of drama, home video can indeed be pivotal as a megaphone for projecting sentiments, aspirations, failings, attainments, history, changes, etc. of Nigeria. Nigerian can truly be effectively pictured and advertised through the home videos.

\section{Literature Review}

Following programmes on the Nigerian project and the pursuit towards rebranding the nation which was introduced during the former President Obasanjo's administration and spearheaded by Prof Dora Akinyili, the then Minister of Communication, researchers and media practitioners have made contributions to the subject indifferent ways.The issue of rebranding presupposes showcasing or projecting Nigeria in good light by promoting the nation's positive appeals.

\section{Background to Nigerian Films}

Ekwuazi (1991: 160) posits that a film industry that aspires to be in the vanguard of national development must do the following as rightly eulogized by Osofisan (1986:49).

- $\quad$ Raise the level of consciousness through liberating the spirits and strengthening the minds of its people;

- $\quad$ Be political, that is - must deal in a positive manner with the existing conditions of oppression;

- $\quad$ Educate, that is - educate to bring out that which is already within, 'give knowledge and truth;

- Clarify issues, by enlightening participants as to why so many negative conditions and images exist in their community in order to eliminate the negative condition and strengthen the positive condition

- $\quad$ Lastly, it must entertain.

Amongst the literature to be reviewed are works done by Akande (2010) and documented in his book, Hazy Pictures: The Arts, Business and Politics of The Nigerian Motion Picture Industry, a collection of articles which he has written in The Nation Newspaper at different times spanning December 21, 2008 to September 25, 2010. These articles satisfactorily provide adequate resource for this study.Adenugba's works (2007) published on the internet are also very rich resource on the Nollywood industry, in general and home video in particular. They effectively treat the subject of showcasing Nigerianthrough the home videos.

While buttressing the need to enhance the nation's cultural values through the films, Akande asks and provide answers to why it should not be a problem even if our movies are made in Igbo, Yoruba, Hausa or Ibibio to project our indigenous cultures with pride. He posits that America respects a nation that speaks her language and exhibits her culture with pride. Referring to the Hindu films which are noted to be making waves around the world through consistency in promoting the Indian culture and now their civilization which is changing the world, he gives an example of the frequency of singing and dancing in the films. He further gives credence to Slumdog Millionaire, the film that won the good film of the decade. According to him, Hindu was the main language spoken in the film which was awarded by Hollywood.

In his article -'Film making - Rebranding: will Nollywood agree to lie (May 3, 2009), hedescribes film making as setting an object against the sun. The obscure reflection being what is largely referred to as fiction because it 
is taken as vivid imagination of reality if the colouration is expunged. Hence, he reflects on the suggestion by the former Minister, Prof Dora Akunliyi at a meeting with the film makers which she implored them to as much as possible reflect Nigeria in positive light in movies; and hopes that the Minister had not just discovered a propaganda tool in the medium of film. He asserts that apart from acts of voodoos in Nollywood films, most representations about the Police, Nigerian politicians, academic system, the power industry, health sector, etcetera, are just appropriate.

In his article -'Americans don't watch Nigerian films' (January 25, 2009), he reports the opinion of Marc Wishengrad, the Emmy nominated Director of Photography and pioneer trainer in the popular SHOOT workshop of the Nigerian Film Corporation (NFC) in Jos. According to him, People throughout the world know what life is like in America without ever setting their feet on its borders which is because movies tell stories of common people and the way they live. "I had little or no idea of what life was like in Nigeria because Nigerian films are not like American movie theatres."

He reiterates that if the above statement is attributed to a film maker who is given to researches and has knowledge of film industry in other parts of the world than America, then you can imagine what an average American, European, Indian would have to say about whether or not they have an idea of Nollywood or what it stands for. He suggests that it is possible that other types of films which have unique stories about African history and experience may attract foreigners. To confirm this, he reports his interaction with Hollywood film maker, Ron Lavey in Canada in 2008, who was feeling excited to be working on Ken Saro Wiwa's story. This rekindled a comment Marc (above) had earlier made:

It will be a wonderful day when Africans tell their own stories, filling the silver screen with their personal stories and not looking to emulate Hollywood style but to look at how stories have been told within one's culture.

Adenugba adds that culture is an essential aspect of aesthetics, particularly because film subsists in culture and also because it is made for audience that has a culture, whether the audience is culturally inclined or not. Hence film tends to reflect the culture or nuances of the philosophy of the society that produces it. Films from China promote the culture of that nation and its people. Films from India reflect the music, dance, dressing and beliefs of the Eastern nations; movies from the United States of America highlight the values and patterns of daily life of that country. Nollywood movies uphold the ways of life and happenings of Nigeria. Films are cultural ambassadors of the society in which they are produced; film is an instrument of cultural proclamation. Each society tells its story. The cultural context of a film helps to explain where the film maker's allegiance lies - whether it lies with culture or something else other than a sense of belonging or inclination to his realm.

According to Tunde Oladunjoye in his article of April 18, 2004 in The Guardian titled 'Cannes Film Festival knocks: where is Nigeria?' the essence of the role which culture plays in societal development is captured as follows:-

I am not aware of any nation that has been able to achieve development without proactive promotion of its essential cultural components, for example, you cannot separate the culture of Japan from that country's economic and technological achievements.

Adenugba further states that cultures facilitate development as well as provide ample raw materials for the film maker to work with. Folklores, myths, fabrics, legends, folk music, folk dance, costume, folk architecture, ritual practices, kingship rites; and other elements and aspects of culture are ready materials that the film maker can explore, borrow, adapt or use verities in his work. He recognizes Lagbaja, Asa, Yinka Davies, Fela Anikupola-Kuti, and King Sunny Ade as Nigerian musicians who have blended their indigenous cultures with music ... that thrill even the foreigners. Tunde Kelani's works gives glamour in films because of his appropriation of culture in storytelling, costume design, set design, music, props, gestures, expression and use of language. Adenugba give examples of cultural hits as: - Igodo (Don Pedro -Obaseki, 2000), Saworoide (Tunde Kelani, 2001), Sango (Obafemi Lasode, 1996), King Solomon's Mine (Compton Bennett and Andrew Marton, 1950)

Succinctly put he claimsthat culture serves as a basis of realism in movies. A work that is built on cultural nuances and conventions of a society is better accepted as an original statement about that society than those that do not. He recognises examples of - Dangerous Twin (Tade Ogidan, 2004), Rattle Snakes I, 11, 111, 1V (Amaka Igwe- Isaac, 1991-1996) as text books about Nigeria in contemporary times while films like False Alarm (2006), Chameleon 1and 11 (2006) are refuted by critics as non-representation of Nigeria because of the un-Nigerian story nature in False Alarm, the conflict is between a Nigerian 'FBI' and Chief Lord LugardDonko. In this article, Adenugba concludes that the thrust of his argument is that every film should reflect as faithfully as possible to the limit that funding and technicalities would allow the culture of its society or the society that is being depicted; only then that the film can gain from the enormous aesthetics benefits that the culture provide for film making.

In Akaoso's article posted online (December, 12, 2009) which is a reaction to Prof Akunliyi's assertion that the Nigerian film industry has contributed to the nation's poor image, he says it is misplaced and out of 
reality. Rather he asserts that Nollywood has done a lot within a short time of its existence to place Nigeria on the map of international film industries.

According to him, over the years, the industry has promoted certain identities and images about the country which in a way have helped to boost the country's reputation. He posits that Nollywood has been able to shoot up the socio-economic profile of the country especially during an era in which the nation was notorious for military coups and political instability. He infers that the production of films in the military epoch, which explores the lives of Nigerians, shows the world that Nigerians are innovative, creative and balanced irrespective of the social upheaval in the country. It also negated the bad image which was generated in the international press about the nation during the period. He adds that the Nigerian motion picture industry has helped to change the perception of the rest of the world about Nigeria and indeed the whole Africa through the films produced. Many people outside the continent especially those who have never set their feet on its soil have come to understand that Nigerians and Africans do not live on trees or walk about naked (as had been speculated previously) nor are we blood thirsty and cruel but we are just like other people in other countries of the world who could be bad, good, greedy, nice because people are people regardless of their nationalities and locations. Furthermore, the industry has shown to the world that our nation is undeniably the giant of Africa. Quoting a BBC world report which once mentioned Nigerian film industry, the author says it "has turned the lights on Africa cinema".

He further writes that over the years, the industry has promoted certain identities and images which critics have frowned at. Some of the images include - ritualistic society, images of a violent society, the poor portrayal of the Nigerian women and a display of a highly ostentatious and an oligarchic society. Imageries and ideas that have largely become norms because profiteering have replaced art. Corroborating Musa (Punch, August, 2006), he informs us that Nollywood is a disappointment (story option); movies should be sociocultural development tools if well-crafted which Nollywood movies are not. Rather, they carry boring stories lines, portraying low intellectualism and technical unprofessionalism. He expresses that although movies with themes and stories of ritual and violence have been explored and exposed events that happen in the country on a regular basis, they also exaggerate and at best have turned many persons into cynics who believe that every other person is out to learn and because films shape society and help orientate the people while also entertaining them; the films have subtlety encouraged people to engage in such amoral and vile activities because they encounter in the films.

From the editorial published in The Economist (December 16, 2010) titled Nollywood: Lights, Camera, Africa ...we understand that movies are uniting the continent and dividing it, too. The author states that it is hard to avoid Nigerian films in Africa. According to him, public buses show them as do restaurants and hotels. He asserts that Nigerian films are popular abroad as they are at home. Ivorien rebels in the bush stopped fighting when a shipment of DVDs arrived from Lagos; Zambian mothers say their children talk with accents learnt from Nigerian movies. When the President of Sierra Leone asked Genevieve Nnaji, a Lagosian screen goddess to join him on a campaign trail, he attracted record crowd at rallies. Millions of Africans watch Nigerian films everyday many more than American fare; and yet Africans have mixed feelings about Nollywood.

Cultural critics complain about 'macabre scenes full of sorcery' in the films. The more alarmists describe Nigerian directors and producers as voodoo priests casting malign spells over audiences in other countries. They talk of the Nigerianization of Africa, worrying that the whole continent has come to 'snap its fingers the Nigerian way.'Nollywood mogul, Ernest Obi, the head of the Actors' Guild, makes no attempt to deny their influence over the continent as he is quoted to have said "we give Africa development and knowledge ... we teach people things; if they call us colonial masters, too bad!"

\section{Theoretical Framework}

Folarin (1998) posits that Mass Communication is a major facet of human communication. As 'that form of communication whose delivery system permits the flow of information to large, diverse and scattered audiences which may also be far removed from the source." Home video is identified as a medium or form of human communication which aptly fit into this definition. This study is underpinned within the framework of agenda-setting theory propounded by McComb and Shaw (1972) which they assert makes mass media to predetermine what issues are regarded as important at a given time in a given society. While the theory does not determine what we actually think, it does ascribe to them the power to determine what we are thinking about. According to Honors Communication Quarterly (2001), the theory is good in explaining why people with similar media exposure place importance to same issues.

Igwo, Audu and Ogbu,(2009) asserts that the main thrust of the Agenda setting theory is that mass media have potentials to structure issues for the public. They refer to Umechukwu (2004:18) which cites McQuail and Windall, and assert that amongst a given range of issues those that get more media attention would grow in their familiarity and perceived importance over a period of time; and those which get less would decline correspondingly. 
According to Cohen (1963), the press (media) may not be successful much of the time in telling people what to think; but it is stunningly successful in telling its audience what to think about.

The favourite method used in determining agenda setting potentials of any medium is usually content analysis of the chosen medium (as well as interview of audience). This is why Agenda-setting is considered as a framework to determine how Nigeria is showcased through the home videos. The choice to study home video televised by the various television stations and Africa Magic was predicated by the fact that Nigeria is thus showcased unrestricted. The viewers are not given choices of films to watch as they are not offered many options at the time of viewing. This further explains the relevance of Agenda -setting as theoretical framework.

\section{Methodology}

Content analysis was employed as a research design to identify how Nigeria has been showcased in the home videos by the video makers. Fifty (50) home video films of English production were carefully selected and watched. Only films shown on different television stations in Lagos and Africa Magic (a cable network station)were watched and analyzed by the researchers; the last thirty (30) minutes of each of the televised film was adopted for analysis. A coding categorization which captured variables like language, story lines/themes, lifestyle, food, gender portrayals, beliefs/norms/values, attitude to other people, natural environment, nature of recreation and relaxation was designed. They were contained within content categories. A coding guide was further created to standardize the instrument for data gathering. It also established uniformity and consistency. The guideconsisted: - serial number, variable,options,value assignment, column as well as remark.Data were inputted as nominal values into standard coding sheets.One hundred and sixty (160) settings and cases were identified.The data analysis was quantitatively done.

\section{Results And Discussion}

The story lines and themes tell of the events that happen in the nation: history and developments; other portrayals and representations were revealed through theinfrastructures and natural settings, people and their appearances, socio-economic status, attitudes, lifestyle and forms of recreation/relaxation.

Of the home video films analyzed, $2 \%$ were epic, $4 \%$ were comedy and $94 \%$ were features. Most of the films were repeatedly televised across the various television stations (as if on demand or request); it was therefore not necessary to note or document the televised stations. Considering the years of production was not important primarily because they were not often displayed by the TV stations apart from the fact that they were not considered relevant to the study; only TVC and Africa Magic consistently displayed them. All the films watched were those for 'General Exhibition'.

$2.5 \%$ of the total content of the film settings were urban-slum, $28.1 \%$ were rural while $69.4 \%$ constituted urban settings.

The buildingsin the home video films were predominantly duplexes/mansions represented by $22.5 \%$, storey buildings $(15.6 \%)$, bungalow and skyscrapers (11.3\% respectively), office complex and shopping complex (8.8\% respectively), clay/mud/thatched (5\%) and stadium (1.9\%). $15 \%$ had no buildings.

Table 2: Types of building/Appearance

\begin{tabular}{|c|c|c|c|c|c|c|c|}
\hline Buildings & Masterpiece & Beautiful & Normal/0rdinar, & Dilapidate & Ugly/shabby/unhygieni & No building & Total \\
\hline Duplex/Mansion & $25(15.7 \%)$ & $11(6.9 \%)$ & & & & & $36(22.5 \%)$ \\
\hline Skyscraper & & & $18(11.3 \%)$ & & & & $18(11.3 \%)$ \\
\hline Storey building & & $25(15.7 \%)$ & $18(11.3 \%)$ & & & & $43(26.9 \%)$ \\
\hline Mud/thatched/clas & & & $3(1.9 \%)$ & & $2(1.3 \%)$ & & $5(3.1 \%)$ \\
\hline Office complex & & $10(6.3 \%)$ & $4(2.5 \%)$ & & & & $14(8.8 \%)$ \\
\hline Shopping complex & & $2(1.3 \%)$ & $12(7.5 \%)$ & & & & $14(8.8 \%)$ \\
\hline Stadium & & & $3(1.9 \%)$ & & & & $3(1.9 \%)$ \\
\hline Indescribable & & & & $3(1.9 \%)$ & & $24(15 \%)$ & $27(16.9 \%)$ \\
\hline Total & $25(15.7 \%)$ & $48(30 \%)$ & $58(36.3 \%)$ & $3(1.9 \%)$ & $2(1.3 \%)$ & $24(15 \%)$ & $160(100 \%)$ \\
\hline
\end{tabular}

Source: Content Analysis, 2012

The above table reveals that of the duplexes/mansions in the home videos, $15.7 \%$ were masterpiece/elegant and $6.9 \%$ was beautiful. The storey buildings were either beautiful or normal/ordinary represented by $15.7 \%$ and $11.3 \%$ respectively. Skyscrapers represented by $11.3 \%$ were all normal/ordinary; $6.3 \%$ of the office complexes were beautiful while $2.5 \%$ were normal/ordinary. The shopping complexes represented by $1.3 \%$ and $7.5 \%$ were beautiful and normal/ordinary respectively. $1.9 \%$ of the buildings which 
represented mud/thatched/ clay were normal/ordinary while $1.3 \%$ were ugly, shabby and unhygienic. $1.9 \%$ of the contents were dilapidated buildings.

Table 3: People and their Appearance

\begin{tabular}{|l|l|l|l|l|l|l|}
\hline People & Flamboyant & Exotic & Modest & Rich & Poor & Total \\
\hline Male Adults & $15(9.4 \%)$ & $4(2.5 \%)$ & $23(14.9 \%)$ & $19(11.9 \%)$ & $5(3.1 \%)$ & $66(41.3 \%)$ \\
\hline Female Adults & $12(7.5 \%)$ & $8(5 \%)$ & $20(12.5 \%)$ & $15(9.4 \%)$ & $5(3.1 \%)$ & $60(37.5 \%)$ \\
\hline Children & & & & $7(4.4 \%)$ & $3(1.9 \%)$ & $10(6.3 \%)$ \\
\hline Male (group) & $5(3.1 \%)$ & & & & & $5(3.1 \%)$ \\
\hline female (group) & $3(1.9 \%)$ & $3(1.9 \%)$ & & & & $6(3.8 \%)$ \\
\hline $\begin{array}{l}\text { Mixed } \\
\text { Mixed }\end{array}$ & $3(1.9 \%)$ & $4(2.3 \%)$ & & & $2(1.3 \%)$ & $9(5.6 \%)$ \\
\hline Total & $38(23.8 \%)$ & $19(11.9 \%)$ & $43(26.9 \%)$ & $43(26.9 \%)$ & $17(10,6 \%)$ & $160(100 \%)$ \\
\hline
\end{tabular}

Source: Content Analysis, 2012

Nigeriansportrayed as adults and children (males and females were viewed singly and/or in groups. In the case of children, there was not much difference in appearance between the males and females hence none was created. $9.4 \%$ of the male adults were flamboyant; $2.5 \%$ were exotic, $14.4 \%$ were modest while $11.9 \%$ were rich and $3.1 \%$ were poor. The female characters were $7.5 \%$ flamboyant, $5 \%$-exotic, $12.5 \%$-modest, $9.4 \%$-rich and $3.1 \%$ - poor. Contents with children were only 10 constituting $4.4 \%$-rich, $1.9 \%$ - poor. Male in groups were seen as flamboyant in $3.1 \%$ settings and women were portrayed as flamboyant and exotic in $1.9 \%$ cases respectively. In groups of men and women shown together, they were seen as flamboyant in $1.9 \%$ settings, exotic in $2.3 \%$ and poor in $1.3 \%$ cases. Combinations of adults (male and female) with children were portrayed in $1.3 \%$ settings as rich and poor respectively.

Viewing in their social classes, $36.3 \%$ of Nigerians constituted the affluent, $12.5 \%$ - poor and middle class respectively, $10 \%$ were natives, $9.4 \%$ represented traditional rulers/council; people at the lower level and political class were $8.1 \%$ respectively and $3.1 \%$ constituted a mixed of different classes of people.

The attitudes of the Nigerian people were identified as follows: - 10\% were domineering and dependent respectively; in $9.4 \%$ cases, they were passive/docile/weak/indifferent; $8.8 \%$ were cruel/hostile/violent/hateful/spiteful and friendly/loving/harmonious respectively; portrayals in the films revealed that in $8.1 \%$ cases, they are discourteous and cooperative/supportive respectively; $6.3 \%$ were independent, $5.6 \%$ were corrupt, $4.9 \%$ were honest, $2.5 \%$ were uncooperative while $0.6 \%$ were unthankful.

Table 4: People/lifestyles

\begin{tabular}{|c|c|c|c|c|c|c|c|c|c|c|}
\hline People & $\begin{array}{l}\text { Traditional/ } \\
\text { Indigenous }\end{array}$ & Foreign & Conservative & Cultured & Decent & $\begin{array}{l}\text { Corrupt// } \\
\text { Indecent }\end{array}$ & Flirtatious & Gay & Modest & Total \\
\hline Male & $\begin{array}{l}15 \\
(9.4 \%)\end{array}$ & $9(5.6 \%)$ & $\begin{array}{l}17 \\
(10.6 \%)\end{array}$ & $\begin{array}{l}2 \\
(1.3 \%)\end{array}$ & $\begin{array}{l}2 \\
(1.3 \%)\end{array}$ & $\begin{array}{l}8 \\
(5 \%)\end{array}$ & $\begin{array}{l}13 \\
(8.1 \%)\end{array}$ & $\begin{array}{l}5 \\
(3.1 \%)\end{array}$ & $\begin{array}{l}6 \\
(3.8 \%)\end{array}$ & $\begin{array}{l}77 \\
48.1 \%\end{array}$ \\
\hline Female & $\begin{array}{l}12 \\
(7.5 \%)\end{array}$ & $6(3.8 \%)$ & $\begin{array}{l}14 \\
(8.8 \%)\end{array}$ & $\begin{array}{l}2 \\
(1.3 \%)\end{array}$ & $\begin{array}{l}3 \\
(19 \%)\end{array}$ & $\begin{array}{l}4 \\
(2.5 \%)\end{array}$ & $\begin{array}{l}7 \\
(4.4 \%)\end{array}$ & & $\begin{array}{l}7 \\
(4.4 \%)\end{array}$ & $\begin{array}{l}55 \\
34.4 \%\end{array}$ \\
\hline Male (group) & $\begin{array}{l}4 \\
(2.5 \%)\end{array}$ & & & $\begin{array}{l}2 \\
(1.3 \%)\end{array}$ & $\begin{array}{l}3 \\
(1.9 \%)\end{array}$ & $\begin{array}{l}1 \\
(0.6 \%)\end{array}$ & & & & $\begin{array}{l}10 \\
(6.3)\end{array}$ \\
\hline $\begin{array}{l}\text { Female } \\
\text { (group) }\end{array}$ & $\begin{array}{l}5 \\
(3.1 \%)\end{array}$ & & & & $\begin{array}{l}3 \\
(1.9 \%)\end{array}$ & & & & & $\begin{array}{l}8 \\
(5 \%)\end{array}$ \\
\hline $\begin{array}{l}\text { Mixed } \\
\text { (male/female } \\
\text { children) }\end{array}$ & & & & & & $\begin{array}{l}2 \\
(1.3 \%)\end{array}$ & & & & $\begin{array}{l}2 \\
(1.3 \%)\end{array}$ \\
\hline Total & $\begin{array}{l}41 \\
(25.6 \%)\end{array}$ & $\begin{array}{l}15 \\
(9.4)\end{array}$ & $\begin{array}{l}31 \\
(19.4)\end{array}$ & $\begin{array}{l}8 \\
(5 \%)\end{array}$ & $\begin{array}{l}11 \\
(6.9 \%)\end{array}$ & $\begin{array}{l}16 \\
(10 \%)\end{array}$ & $\begin{array}{l}20 \\
(12.5 \%)\end{array}$ & $\begin{array}{l}5 \\
(3.1 \%)\end{array}$ & $\begin{array}{l}13 \\
(8.1 \%)\end{array}$ & $\begin{array}{l}160 \\
(100 \%)\end{array}$ \\
\hline
\end{tabular}

Source: Content Analysis, 2012 
The lifestyle of Nigerian people as portrayed in the Nigerian home video films analyzed range from traditional/indigenous represented in $25.6 \%$ of the settings, conservative $-19.4 \%$, flirtatious $-12.5 \%$, foreign and indecent $-9.4 \%$ respectively, modest $-8.1 \%$, decent $-6.9 \%$, cultured $-5 \%$ and Gay $-3.1 \%$. The above table further reveals that Nigerian males dominated the video scene with $48.1 \%$ representation over $34.4 \%$ female representations. Nigerian people have more showings as individuals rather than groups. Children (1.9\%) and mixed /sex groups have minority showing. Largely, it shows that Nigerians are portrayed as traditional/indigenous people in one out of four (4) cases represented by $25.6 \%$, as conservative in $19.4 \%$, as flirtatious in $12.5 \%$ cases, as corrupt/indecent in $10 \%$ cases, as foreign in $9.4 \%$ cases, as modest in $8 \%$ cases, as decent in $6.9 \%$ cases, as cultured in $5 \%$ cases and as gay in $3.1 \%$ cases.

Nigerian lifestyles were further portrayed through dressing in $30 \%$; language $-10.6 \%$, beliefs were represented in $9.4 \%$ cases; $7.5 \%$ cases through food, music and as fetish in $6.3 \%$ respectively, singing and dancing $-1.3 \%$ respectively; sexuality $-5 \%$ and African traditional religion (ATR) and ceremony $-3.1 \%$ respectively. $16.3 \%$ had no representation of Nigerian lifestyle. In most cases, characters in offices were shown dressed in suits and other formal clothing.

From the contents of the home videos analyzed, settings which had trees/plants/farms constituted $26.3 \%$ cases, $3.8 \%$ had streams/seas/rivers. There were hills/mountain in $1.3 \%$ settings, $67.5 \%$ had no representations of any sort. Tourist centres and attractions like waterfalls, caves, mountains, resort centres and historical and monumental places were rarely seen. Forms of recreation/relaxation were indicated as following: - indoor games were seen in 1.3\% cases, $1.9 \%$ showed games like table tables and snookers and swimming respectively,Nigerians were revealed at the beaches, sight-seeing, outdoor games and partyingin $3.1 \%$ respective cases.

\section{Showcasing Nigeria through the Home Videos}

Through portrayals of the home videos, it is very easy to recognize Nigerians as very religious people. The producers of the films have done a lot to project the religious practices, beliefs, norms and values of the people. Christianity (with different shades and structures) and African Traditional Religion (ATR) have the highest representations in the home videos which were analyzed. Islam, occultism/cultism, Ritualism, witchcraft and fetish acts amongst others are usually and effectively portrayed in the films, People would often seek solutions to problems under the cover of religion. Notwithstanding people's level of sophistication and foreign lifestyle, Nigerians can choose to settle matters through traditional means. This is reflected in Evil Finger (2005) as the daughter of a man who was defrauded and killed by his brother-in-law (now running his business) goes to meet the elders of their family to summon the suspect to absorb himself of all accusations leveled against him. Through spiritual means, the native doctor is able to cause the culprit to go to the village to answer to charges against him. Not very many home videos are shown without actual portrayals or subtle suggestions of witchcraft and fetish practices.

Nigerian cultures are undoubtedly revealed in the films packaged in the home videos. The story lines/themes, lifestyles, foods, norms and values,and even manner of dressing reveal the ways of life of the people; sometimes, indigenous languages are introduced into the film plots through interjection of vernacular (to identify the cultural settings of the story). Such languages include Yoruba, Igbo, Efik- Ibibio, Hausa and Ijaw.In films with traditional and royal settings, the portrayals of the traditional institutions are usually shown with their representations as dressing, guards and other types of traditional aesthetics. Politicians, traditional title holders (people addressed as 'chief') and some wealthy men most often appear in traditional clothings like 'agbada'.The home video film - The Plain Truth (undated) reveals the culture where a woman who is not able to give birth to children marries another woman to bear children in her name. In this case, the young wife and her family are deceived to believe that she is being married for the woman's son, who lives abroad. The 'woman- husband's brother- in- law would go to sleep with the young wife at night, when she would have been drugged. The film Stronger Than Pain (2008) is purely traditional in every sense. Having Igbo background as setting, almost everything - from props to costumes is traditional. The film gives expression of a typical traditional society. All the cooking and eating instruments are traditional. The drinks - palm wine, manner of cooking, water pots, settings and lifestyles truly reveal a typical Nigerian native village. In almost all the home videos with traditional settings, the maidens would always be shown going to/or returning from the streams (through foot paths) with water pots on their heads. The film - Who will tell the President (2001), seems to portray almost every aspect of Nigeria - ranging from story line through the lifestyle of the people to geographical landmarks (including natural structures - like caves, streams, rocks, forest and farmlands). It is also the first and only Nigerian film watched for analysis which gives expression of activities in the air space. In most cases, when people are shown eating in home videos, they usually eat jollof rice or white rice and stew. Only in few cases do we see melon soup and garri and sometimes pepper soup as in Super Story - Sister Sister and Stronger Than Pain.Nigerian children are in most cases portrayed as courteous and rarely discourteous.It can be assumed that Nigerians are groomedto be courteous from childhood, as a young boy is shown opening a door and allowing his 
sister to enter first before him in Two Sides of the coin(a serial feature film currently running).Trecia Esigie's serial film, Pradah (2012) is a very impressive attempt to showcase Nigeria in diverse ways. Nigerian stars and talents in football and film making industries are advertised through their involvement as actors in the film (which projects challenges in the Nigerian female and male football teams as well as the film industry), even as the stories/themes tell of pains and values of common people. The Nigerian colours and flags are portrayed.

In the film - Super Story: Invitation to Thunder, the struggle to board commercial buses at the bus stop in highly concentrated locations like Oshodi or Orile is revealed. We see many commuter buses with Lagos State Commercial vehicle colours. The film, Spare my life (2009) also clearly reveals busy Lagos in its bustling and hustling characteristics.

Unfortunately, certain kinds of dressing do not depict acceptable standards of the Nigerian cultures. While they may be borrowed, they are also suggestive of perverse lifestyle. These portrayalsarevery unrealistic.Certain dressing patterns seem unrealistic for the intended settings. For example - a village woman wearing lipstick to sleep at night with beautifully polished finger and toe nails. This suggests that irrespective of class and settings, Nigerians are very exposed and sophisticated. Often, young men in home videos who may have lived abroad and visit home would usually be seen wearing earring in one ear (left). Fun loving men are also sometimes shown with earring in one ear (left). While this may portray them as gay and irresponsible, the culture is very un-Nigerian.

Most of the films show that majority of Nigerians live in affluence and in urban settings; the low and middle level people live as comfortable as the very rich.The houses in Nigeria are shown to be mostly masterpiece, elegant and beautiful.Nigerian men and women are portrayed as usually flamboyant and rich over those who are modest.In the film - Evil Finger (2005),it is suggested that anybody can live in any kind of house as desired. This is deduced from seeing a manager whose salary was N150, 000 per month in 2005 (when the film was produced) live in a mansion. In the film, Two Sides of a Coin, the house of a rich man's driver looks like that of a middle class person. This conveys the impression that at whatever level, Nigerians can live so comfortably.

Nigerians are portrayed with different kinds of attitudes yet both men and women are mostly as dependent and domineering over and amongst other types of attitudes; they can be as patriotic as they are corrupt.They can do anything to get rich not minding the consequences. There was not one film analyzed that the corrupt nature of the people was either not obviously projected or suggested. However, from Sound of Love(undated), we realize that it is possible to find some patriotic Nigerians.A Nigerian houseboy - Francis Duru called Silas to a foreigner couple who areswindlers protects Nigerian image from being battered by his bosses (husband and wife), who have been fraudulently dispossessing people of their hard currencies. The house boy is asked to pose as a bank manager when their victims arrive. He agrees but intimates the Economic and Financial Crime Commission (EFCC) officials, who lay surveillance on the culprits and arrest them. The film is an exceptional positive contribution towards rebranding the Nigerian image. Many more productions like this would guide the viewing audience on actions to take in similar situations.

The film makers do not overlook the security challenge prevalent in the country. Most houses in the urban setting where the exteriors were portrayed often have gates and gatemen who would open them to allow access. Nigerians are therefore depicted as being highly security minded.

Despite, certain accurate, sometimes flattery and other times unkind and harsh depictions of Nigeria and its people in the indigenous movie industry (mostly home videos), infrastructures on the nation's roads as well as geographical landmarks and natural (external) settings like rocks, caves, farmlands, amongst others are scarcely revealed. Very little is done to projectopportunities and potentials in tourism, business and investment available in the country in the films. A foreigner who attempts to find out how Nigerians relax through the home videos would believe that highly placed and seeming comfortable Nigerians rarely play games; they usually relax partying, in the hotel and clubs; only the jobless and unskilled workers do (at their leisure time).People who play games like draught and ludo in home video films are usually those men who are not gainfully employed, unskilled workers/artisans or low level workers (after work). In very few home video films like Family Ties 1 (serial feature film)is Nigeria portrayed with individuals playing pianos for relaxation. Sophisticated men and women, irrespective of social class, career or business lines are usually shown to relax in clubs or hotels. Only in Indulgence (2004) amongst all the films that were studied did we see people playing snooker.

\section{Conclusion And Recommendations}

The home video is a medium of communication which different individuals, people and organizations can utilize for different purposes and advantage (and disadvantage). As Nigerian's prominent promoter of cultures, people and products, the Nigerian government needs to give attention to the industry and its offerings even as collaboration with the film makers is enhanced towards showcasing the nation and its numerous potentials and opportunities. Throughthe film offerings, the film makers should ensure that productionof the 
films take into consideration the Nigerian project and the need to export its cultures as well as positively market opportunities and potentials available in the country.The film makers should understand their roles as marketers for the nation and attempt to ensure that the stories and portrayals in the home video films capture the true essence of who Nigerians are, amongst other things. Films should be produced to consciously project the nation's investment opportunities, recreation centres, tourist centres and attractions. Portrayals in Nigerian home videos should capture places of excitement in the country like: Protea, Sheraton, Hilton hotels, amongst others.Agricultural produce, natural resources, solid mineral of the nation should be promoted amongst other portrayals in the home videos. Nigerian symbols like the flags, currencies, coat of arms should be captured in the films.

Monumental and historical structures and definite environmental representation like Zuma rock, Tafewa Balewa Square (race course), Tinubu Square can be captured as montage in the films. Just as it is unimaginable to see France without the Eiffel Tower, the global cultural icon of the country, these monumental and historical structures should not be disregarded in the home video films.

Attempts should be made to showcase the beautiful sceneries of Nigeria in the home videos: waterfalls, games reserves, ranches and the beaches with the large groves of coconut trees.

Film makers should be realistic in their portrayals: matching characters with their expected lifestyles for example, a driver (no matter who he works for should be made to live in an accommodation fitted for him; a villager should not be given attributes of an urbane character).

It is important to inform the world about Nigeria's kind of food and delicacies; hence, indigenous foods should be served at meal time. The viewing public should be told how Nigerians eat at different times and settings. Apart from eating main meals, scenes should be created where people eat indigenous snacks like groundnut or coconut, for example. It would be impossible to see people eat meals that do not exclusively portray Indian culture in any of their films.

In order for the video makers to be effective in showcasing Nigeria with its rich endowments, the film makers and government would need to liaise with the banks and other financial institutions for funding, sponsorship and other necessary supports towards producing acceptable films. Just as portfolios are created for funding projects in oil \& gas, telecommunication, aviation, agriculture and other viable industries, funding organizations should be part of projects to showcase the nation through their funding supports.

\section{Reference}

[1]. Adenugba, Olushola Oladele (2007), 'Culture as an aspect of film aesthetic' filminnigeria: a blog on Nigerian film industry

[2]. Adenugba, Olushola Oladele(2007), 'The history and development of the Nigerian motion picture industry' filminnigeria: a blog on Nigerian film industry

[3]. Adenugba, Olushola Oladele (2007), 'Motion picture and the Nigerian image' filminnigeria: a blog on Nigerian film industry

[4]. Akande, V. (2010), Hazy Pictures: The Arts, Business and politics of the Nigerian Motion Picture industry, Ibadan: Kraft Books Ltd

[5]. Akeh, K. (2008), The Movie Industry in Nigeria, Nigeria: Speedy Prints Ltd

[6]. Ekwuazi, Hyginus, (1991), "The Communicative Import of film in National Development" in Unoh, Solomon (ed) (1991), Tropical Issues in Communication Arts, Uyo: Modern Business Press

[7]. Folarin, B. (1998), Theories of Mass Communication: An introductory Text, Ibadan: Stirling-Horden Publishers (Nig) Ltd

[8]. Gauntlett, David, (2002), Media, Gender and Identity: An introduction, London: Routledge

[9]. Hamley, Katherine, (undated), Media Use in Identity Construction, www. Aber.ac.uk/media/students/k19802

[10]. Haynes, J (2005), 'Nollywood: What is in a name?' nollywood.net Nigeria\& African film makers, July 2004

[11]. Igwo, A \& Audu M, (2009), 'Cultural Imperialism as a Dysfunction of a Globalised Media: The Implications for The Nigerian Society,'International Journal of Broadcasting andCommunication Technology, Department of Broadcasting, Adebola Adegunwa School of Communication, Lagos State University

[12]. Lacey, Nick, (2009),Images and Representation: Key Concepts in Media Studies, Hampshire: Palgrave Macmillan

[13]. Macquail, Dennis (2005),Macquail Mass Communication Theory, London: Sage Publications Ltd

[14]. McComb's M. \& Shaw Daniel (1972), 'Agenda-setting function of the Mass Media in Public Opinion Quarterly (pp 176-185) Honors: Communications Capstone Spring 2001 Review

[15]. Merriam-Webster Unabridged Dictionary (Online, undated), wwe.meriam-webster.com/dictionary/showcase

[16]. Nelmes, Jill (2005), An Introduction to film Studies, London: New York: Routledge

[17]. 'Nollywood: lights, camera, Africa - Movies are uniting a disparate continent and dividing them, too' (Dec 10, 2010), The Economist

[18]. Nwaoko, Sam (2012), 'Can our films be tools for change?' Ibadan: Labs Deroy Centre

[19]. Oxford Advanced Learners Dictionary (2000), London:Oxford University Press

[20]. Sunday, Uduakobong (2012), Nigerian Image in the Home Videos, PG.D project, Adebola Adegunwa School of Communication, Lagos State University.(Unpublished)

[21]. Tranparency International Report: 2000, 2009

[22]. United Nations Report, 2010 